Hobson, P. N. \& ManN, S. O. (1955). J. gen. Microbiol. 13, 420-435

\title{
Some Factors Affecting the Formation of Iodophilic Poly- saccharide in Group D Streptococci from the Rumen
}

\author{
By P. N. HOBSON AND S. O. MANN \\ The Rowett Research Institute, Bucksburn, Aberdeenshire
}

SUMMARY : Of 25 isolates of $\alpha$-haemolytic group $D$ streptococci from the rumens of calves (Mann \& Oxford, 1955), 7 produced intracellular iodophilic polysaccharide when grown aerobically or anaerobically in agar media containing starches of various origins, amylopectin, maltose, maltotriose, glycogen, amylose and amylopectin dextrins, or amylose glycollate. The iodophilic polysaccharide was not produced from glucose, sucrose, trehalose, glucose-1-phosphate, glucose-6-phosphate, cellobiose or amylose. These results are discussed in the light of the amylolytic action of the bacteria and known enzymic mechanisms of starch-type polysaccharide formation.

In liquid media the polysaccharide was only produced from maltose when the cells were held at a $\mathrm{pH}$ value between 5 and 6 , either by adjusting the reaction of the medium after the initial growth period, or by transferring the cells to a maltose solution buffered at the correct $\mathrm{pH}$ value and incubating further. Under the correct conditions polysaccharide formation was rapid. The polysaccharide was obtained in a partially purified form from the cells and appears to be unlike most 'starches' from bacteria so far reported. A possible explanation of the mode of development of an iodophilic reaction in streptococci in the rumen is given.

The presence in the intestines of animals and birds of bacteria which give a 'starch-' or 'glycogen-' like reaction with iodine in potassium iodide solution has been noted by many workers (e.g. Klein, Schmid \& Studt, 1937; Quin, 1943; Baker \& Nasr, 1947; Van der Wath, 1948; Baker, Nasr, Morrice \& Bruce, 1950; Moir \& Masson, 1952; Masson, 1954). Most of these iodophilic organisms are coccoid forms associated with the breakdown of starch granules, and sometimes cellulose, in the digesta, and the iodine-staining polysaccharide of these organisms can easily be seen in wet films. However, a good and rapid production of iodophilic polysaccharide in cultures of intestinal organisms has seldom been attained. MacPherson (1953) isolated 25 strains of amylolytic streptococci from sheep rumen, but these cocci were apparently only feebly- or non-iodophilic in vitro. (Later experiments, similar to those described below, showed that they were iodophilic under the correct conditions.) Higginbottom \& Wheater (1954) isolated Streptococcus bovis from cattle, goat and sheep rumen, and these cocci were stated to produce iodophilic colonies on soluble starch agar after 3-4 days of incubation. Nasr \& Baker (1949) showed that washed suspensions of Clostridium butyricum from pig caecum gave a strong iodine reaction after incubation for $\mathbf{3}$ days in buffered glucose-1-phosphate. The synthesis of bacterial polysaccharide in the rumen would appear to be much more rapid than this.

Mann \& Oxford (1955) isolated and classified 58 strains of group D streptococci from the rumen of calves of different ages; 42 of these isolates were amylolytic, and of $25 \alpha$-haemolytic organisms in this group, 7 produced densely 
iodophilic colonies when incubated for 3 days on a $0.5 \%$ starch agar medium. These organisms appeared to be identical with those isolated from sheep by MacPherson (1953). Continuing our studies of these and other intestinal bacteria (Hobson \& MacPherson, 1952, 1954; Hobson \& Nasr, 1951) it was decided to investigate the iodophilic polysaccharide of a typical calf rumen streptococcus (no. 18C6). As a preliminary the substrates for polysaccharide formation were determined. At first it was not possible to obtain densely iodine-staining cells in a liquid medium, so attempts were made to prepare the polysaccharide from cells grown on agar slopes. It was difficult to obtain enough cells in this way, so an investigation was made to determine the conditions necessary for the optimum formation of iodophilic polysaccharide in liquid media. The results of these experiments and a preliminary account of the polysaccharide obtained are given in this paper.

\section{ME'THODS}

The isolation of the organisms used was described by Mann \& Oxford (1955). Stock cultures were kept in Robertson's cooked meat broth, and inoculations (4 drops/100 ml.) of the experimental media were made from $24 \mathrm{hr}$. nutrient broth cultures.

Media. The basal medium consisted of $1 \%$ Bacto yeast extract, $1 \%$ Bacto tryptose, $\mathbf{0} \cdot 1 \% \mathrm{KH}_{2} \mathrm{PO}_{4}$, in distilled water, the $\mathrm{pH}$ adjusted to $7 \cdot 6$, sterilized by autoclaving at $120^{\circ}$ for $15 \mathrm{~min}$; agar $(2 \%)$ was added for plates. Carbohydrates were sterilized by filtration and added in concentrated solution; starches were autoclaved. Where possible the carbohydrates were dissolved in distilled water, but it was found necessary to dissolve some of the starches and dextrins in dilute $(c .0 \cdot 3 \mathrm{~N}) \mathrm{NaOH}$ in a boiling water bath and then to neutralize the solution with sulphuric acid before sterilizing. In the buffered media the $0 \cdot 1 \% \mathrm{KH}_{2} \mathrm{PO}_{4}$ was omitted and appropriate mixtures of $\mathrm{KH}_{2} \mathrm{PO}_{4}$ and $\mathrm{K}_{2} \mathrm{HPO}_{4}$ added to give a final concentration of $0 \cdot 1 \mathrm{~m}$-phosphate. The $\mathrm{pH}$ values of the media were checked with BDH Capillators (British Drug Houses Ltd., Poole, Dorset) using at least two indicators where possible.

Carbohydrates. Potato starch was a commercial sample (Hopkin and Williams Ltd., London). For the smooth pea, waxy maize, wheat and maize starches we are indebted to Dr W. J. Whelan, Chemistry Department, University College, Bangor. Holotrich starch (stored by rumen protozoa) was given by Dr A. E. Oxford (Oxford, 1951). The two amylose samples $(a, b$, Table 1) were precipitated from potato starch by the thymol-alumina method of Hobson, Pirt, Whelan \& Peat (1951). Amylopectin was prepared from potato starch after thymol precipitation of the amylose (Bourne, Donnison, Haworth \& Peat, 1948). Soluble starch and glucose were obtained from British Drug Houses Ltd.; maltose hydrate from T. Kerfoot and Sons, Vale of Bardsley; 'dextrine' from G. Gurr Ltd., London; glycogen from L. Light and Co. Ltd., Colnbrook, Bucks. Two samples of dipotassium glucose-1-phosphate were used, one from British Drug Houses Ltd., and the other prepared from potato starch by the method of MacCready \& Hassid (1944). Glucose-6-phosphate was 
used as the barium salt. Maltotriose was prepared by the action of salivary $\alpha$-amylase on amylose followed by separation of the products on a charcoalcelite column (Whistler \& Durso, 1950). Amylose glycollate (1:10) was prepared from amylose by treatment in alkali with monochloroacetic acid as described by Peat, Bourne \& Thrower (1947) for starch. The dextrins were prepared by acid hydrolysis of amylose or amylopectin until the iodine stain was reddish purple. The solutions were then neutralized, dialysed, the nondiffusible material evaporated to small volume, and the dextrins precipitated by addition of ethanol (5-6 vol.), then washed and dried by trituration with ethanol followed by ether. Portions were used for determination of the blue value (Bourne, Haworth, Macey \& Peat, 1948), conversion to glucose by acid, and reducing power as maltose. The absence of oligosaccharides after dialysis and precipitation was confirmed by paper chromatography. The reducing power and iodine stain of the amylose dextrins suggested an average chain length of about 20 units, but the dextrins would be very heterogeneous. The average chain length of the amylopectin dextrin is impossible to assess, because of the branch linkages, but it had a reddish purple iodine stain and a reducing power equivalent to $c .4 \%$ of an equal weight of maltose.

\section{RESULTS}

\section{Formation of iodophilic polysaccharide on solid media}

In the initial experiments all isolates which produced iodophilic colonies on starch were used to test the various carbohydrate substrates. The plates were incubated aerobically for 3 days at $38^{\circ}$ as this gave a good iodine reaction in the cells; later it was found that a shorter time of incubation was enough; the results are shown in Table 1 . There was good growth on all substrates. A control experiment with $1 \%$ maltose as substrate showed that iodophilic polysaccharide was formed also under strictly anaerobic conditions. The hydrolysis of amylose was complete immediately around the colonies but some material remained unhydrolysed at a greater distance. No polysaccharide was produced from glucose, but it was produced from maltose, and it might be expected from higher analogues of maltose; but an interesting point is that although amylose was hydrolysed by the bacteria, presumably initially to maltose and maltotriose (see Discussion) no iodophilic polysaccharide was formed from it. The only polyglucoses which yielded polysaccharide were all entirely, or preponderantly of a branched chain structure. It seemed worth while to test maltotriose and straight- and branched-chain dextrins and amylose glycollate, the substituent groups of which act like branch linkages to the action of enzymes such as $\beta$-amylase. Higher concentrations of amylose and various concentrations of maltose were also included to see whether these affected the production of polysaccharide. Sucrose was tested because a strain of Clostridium butyricum produced an iodophilic polysaccharide from this sugar (Hobson \& Nasr, 1951). Two typical organisms were used for these tests, and the results are given in Table 2 . When no carbohydrate was present in the agar growth was rather scanty and no iodophilic polysaccharide was formed. The 
growth of the organisms on plates containing glucose-1-phosphate was scanty, so a further test was made to see whether actively growing cells utilized this carbohydrate. Glucose was used for the initial growth to prevent the formation of polysaccharide which might have rendered later results difficult to interpret. Glucose $(2 \%)$ plates were inoculated and incubated; at $24 \mathrm{hr}$.

\section{Table 1. Formation of intracellular iodophilic polysaccharide by rumen streptococci on solid media}

Basal medium given in text. All carbohydrates in $0.5 \%$ concentration. Plates incubated 3 days aerobically at $38^{\circ}$. $\mathrm{C}=$ complete hydrolysis of substrate (i.e. lack of colour on flooding plate with $\mathbf{I}_{2}+\mathrm{KI}$ solution; $\mathbf{P}=$ partial hydrolysis;,+++ , etc. $=$ degrees of iodine colour of colonies; $+++=$ blue black; $-=$ no colour; $*=$ not tested.

\begin{tabular}{|c|c|c|c|c|c|c|c|}
\hline \multirow[b]{2}{*}{ Substrate } & \multicolumn{7}{|c|}{ Organisms } \\
\hline & $18 \mathrm{C} 6$ & $19 \mathrm{C}_{1}$ & $16 \mathrm{MI}$ & $18 \mathrm{C} 2$ & $18 \mathrm{M} 1$ & $18 \mathrm{C} 7$ & $18 \mathrm{M} 2$ \\
\hline & \multicolumn{7}{|c|}{ Reactions } \\
\hline & C & $\mathrm{C}$ & $\mathbf{P}$ & C & $\mathrm{c}$ & C & c \\
\hline 'Dextrine' & + & + & + & + & ++ & ++ & ++ \\
\hline Glucose & - & - & - & - & - & - & - \\
\hline \multirow[t]{2}{*}{ Glycogen } & $\mathrm{C}$ & $\mathrm{C}$ & C & c & $\mathrm{C}$ & C & C \\
\hline & ++ & + & + & $+t$ & + & + & ++ \\
\hline \multirow[t]{2}{*}{ Maltose } & ++ & + & + & +++ & +++ & +++ & ++ \\
\hline & $\mathrm{C}$ & C & C & $\mathrm{C}$ & $\mathrm{C}$ & $\mathrm{C}$ & C \\
\hline \multirow[t]{2}{*}{ Holotrich starch } & + & + & + & + & \pm & ++ & ++ \\
\hline & $\mathbf{P}$ & $\mathbf{P}$ & $\mathbf{P}$ & $\mathbf{P}$ & $\mathbf{P}$ & $\mathbf{P}$ & $\mathbf{P}$ \\
\hline \multirow[t]{2}{*}{ Amylose, $a$} & - & - & - & - & - & - & - \\
\hline & $\mathbf{P}$ & $\mathbf{P}$ & $\mathbf{P}$ & $\mathbf{P}$ & $\mathbf{P}$ & $\mathbf{P}$ & $\mathbf{P}$ \\
\hline \multirow[t]{2}{*}{ Amylose, $b$} & - & - & - & - & - & - & - \\
\hline & $\mathrm{C}$ & $\mathrm{C}$ & $\mathrm{C}$ & $\mathrm{C}$ & $\mathrm{C}$ & * & $\mathrm{C}$ \\
\hline \multirow[t]{2}{*}{ Smooth-pea stareh } & + & + & + & + & + & & + \\
\hline & $\mathrm{C}$ & C & $\mathrm{C}$ & C & $\mathrm{C}$ & C & C \\
\hline \multirow[t]{2}{*}{ Waxy-maize starch } & + & + & + & + & + & + & ++ \\
\hline & $\mathrm{C}$ & $\mathrm{C}$ & $\mathrm{C}$ & $\mathrm{C}$ & $\mathrm{C}$ & C & $\mathrm{C}$ \\
\hline \multirow[t]{2}{*}{ Soluble starch } & ++ & ++ & ++ & ++ & ++ & ++ & ++ \\
\hline & $\mathbf{C}$ & $\mathbf{C}$ & $\mathrm{C}$ & $\mathrm{C}$ & $\mathrm{C}$ & $\mathbf{C}$ & $\mathrm{C}$ \\
\hline \multirow[t]{2}{*}{ Wheat starch } & ++ & ++ & ++ & ++ & \pm & \pm & + \\
\hline & $\mathrm{C}$ & $\mathbf{C}$ & $\mathbf{C}$ & $\mathrm{C}$ & $\mathrm{C}$ & $\mathbf{C}$ & $\mathrm{C}$ \\
\hline \multirow[t]{2}{*}{ Maize starch } & ++ & ++ & ++ & ++ & ++ & + & ++ \\
\hline & C & C & C & $\mathrm{C}$ & $\mathbf{C}$ & C & C \\
\hline \multirow[t]{2}{*}{ Amylopectin } & + & + & + & ++ & ++ & + & ++ \\
\hline & C & C & $\mathrm{C}$ & C & C & C & C \\
\hline Potato starch & + & + & + & ++ & + & ++ & + \\
\hline
\end{tabular}

intervals a plate was taken and a sterile filter-paper disk dropped on to a portion of the agar having a considerable number of colonies. The paper was then saturated with sterile 5\% glucose-1-phosphate solution and the plate incubated for a further $\mathbf{2 4} \mathrm{hr}$. to allow the glucose-1-phosphate to diffuse into the surrounding medium. It was expected that if glucose-1-phosphate were utilized at all a suitable concentration would be found at a certain distance 
from the paper and the colonies in that region would become iodophilic. This experiment was repeated on plates incubated for $24,48,72$ and $96 \mathrm{hr}$. after the initial inoculation, but no iodophilic polysaccharide was formed. This suggests that the cells grown on glucose were unable to utilize glucose-1-phosphate.

Table 2. Formation of intracellular iodophilic polysaccharide by rumen streptococci on solid media

Basal medium given in text. Plates were incubated for 3 days aerobically at $38^{\circ}$.

\begin{tabular}{|c|c|c|}
\hline \multirow{3}{*}{$\begin{array}{l}\text { Substrate } \\
(\%, w / v)\end{array}$} & \multicolumn{2}{|c|}{ Organism } \\
\hline & $18 \mathrm{C} 6$ & $19 \mathrm{Cl}$ \\
\hline & \multicolumn{2}{|c|}{ Reactions } \\
\hline Cellobiose $(0 \cdot 5)$ & - & - \\
\hline Maltose $(\mathbf{1} \cdot \mathbf{0})$ & +++ & + \\
\hline Maltose $(0 \cdot 1)$ & - & - \\
\hline Glucose $(1 \cdot 0)$ & - & - \\
\hline & C & C \\
\hline Amylose dextrin $(a ; 0.5)$ & - & - \\
\hline & $\mathrm{C}$ & $\mathrm{C}$ \\
\hline Amylose dextrin $(b ; 1.0)$ & $\begin{array}{c}+++ \\
\mathrm{C}\end{array}$ & $\begin{array}{l}+ \\
\mathrm{c}\end{array}$ \\
\hline Amylopectin dextrin $(\mathbf{1} \cdot 0)$ & $+t+$ & + \\
\hline Maltotriose (2.0) & $\underset{\mathbf{P}}{++}$ & * \\
\hline Amylose $(1 \cdot 0,2 \cdot 0)$ & - & * \\
\hline Amylose glycollate $(1: 10 ; 0.5)$ & $\begin{array}{c}\text { C } \\
+++\end{array}$ & $*$ \\
\hline Sucrose $(2 \cdot 0)$ & - & - \\
\hline Trehalose $(0 \cdot 5)$ & - & - \\
\hline Glucose-1-phosphate $(0 \cdot 5,2 \cdot 0)$ & $-\dagger$ & $-\dagger$ \\
\hline Glucose-6-phosphate $(0 \cdot 5)$ & $-\dagger$ & $-\dagger$ \\
\hline
\end{tabular}

After $17 \frac{1}{2} \mathrm{hr}$. incubation on $2 \%$ maltose agar a good growth was apparent, but the colonies were not iodophilic; after a further $6 \mathrm{hr}$. the colonies were strongly iodophilic, and the iodine stain increased in intensity on further incubation. After 4 days the colonies seemed to contain many dead and disintegrating cells, and observations were not continued. In some starch and glycogen plates conditions appeared to become suitable for iodophilic polysaccharide formation after about 2 days. The appearance of iodophilic and non-iodophilic colonies is shown on $\mathrm{Pl}$. 1, fig. 1.

\section{Formation of iodophilic polysaccharide in liquid media}

In a preliminary attempt to prepare the polysaccharide, organisms $18 \mathrm{C} 6$ and $19 \mathrm{C} 1$ were each inoculated into two basal broths containing respectively $2 \%$ maltose and $2 \%$ glucose, and incubated aerobically for 7 days. Tests at daily intervals showed that the organisms from the glucose medium contained 
no iodophilic polysaccharide, and those from the maltose medium only a small amount which did not increase with time of incubation. It was evident, therefore, that the conditions in the liquid medium were not as favourable to the formation of polysaccharide as on the solid medium. Since the constituents of the media were the same, except for the agar, it did not seem likely that a nutritional factor was lacking in the liquid medium, and of other possibilities the $\mathrm{pH}$ value of the medium was the main variable. The initial $\mathrm{pH}$ value of the maltose broths was $7 \cdot 6$, but this rapidly decreased to $4 \cdot 4$ during the growth of the cells. As a first experiment, therefore, an attempt was made to keep the medium only slightly acid. Two broths containing $2 \%$ maltose, one buffered at $\mathrm{pH} 7$ and the other unbuffered $(\mathrm{pH} 7 \cdot 6)$ were inoculated and incubated in screw-top bottles. (In the following experiments the media were incubated in sealed bottles, without special precautions to exclude air on opening and closing the bottles; these are referred to as aerobic incubations.) The results suggested that more polysaccharide might be formed if the medium were kept at a $\mathrm{pH}$ value of $5-5 \cdot 5$ after the initial growth period.

\section{Formation of polysaccharide by cells in buffered maltose broths}

Basal broth containing $2 \%$ maltose and buffered at different $\mathrm{pH}$ values was inoculated with streptococcus $18 \mathrm{C6}$. At intervals, portions of the cultures were removed and centrifuged to test the iodine stain of the cell sediments, the microscopic appearance of the cells, and the $\mathrm{pH}$ value and reaction with Fehling's solution of the supernatant liquids. The results are shown in Table 3. As

Table 3. Formation of intracellular iodophilic polysaccharide by a rumen streptococcus in buffered liquid media

The medium is the basal one given in the text with the addition of maltose $(2 \%, w / v)$. Iodine stains: $\mathrm{g}=$ green $; \mathrm{pb}=$ purple black; $\mathrm{y}=$ yellow; $\mathrm{bl}=$ greyish blue.

The cells were capsulated at all times and Fehling's test showed some sugar present in the cultures after $42 \mathrm{hr}$.

\begin{tabular}{|c|c|c|c|}
\hline \multirow{2}{*}{$\begin{array}{c}\text { Time of } \\
\text { incubation }(t) \\
(\mathrm{hr} .)\end{array}$} & \multicolumn{2}{|c|}{ pH value } & \multirow{2}{*}{$\begin{array}{c}\text { Iodine stain of } \\
\text { bacterial sediment }\end{array}$} \\
\hline & Initial & At time $t$ & \\
\hline 17 & $\begin{array}{l}5 \cdot 5 \\
6 \cdot 0 \\
6 \cdot 3 \\
7 \cdot 1 \\
7 \cdot 6^{*}\end{array}$ & $\begin{array}{l}4 \cdot 5 \\
4 \cdot 3 \\
5 \cdot 0 \\
6 \cdot 6 \\
4 \cdot 1\end{array}$ & $\begin{array}{c}\mathrm{g} \\
\mathrm{pb} \\
\mathrm{g} \\
\mathrm{y} \\
\mathrm{g}\end{array}$ \\
\hline 23 & $\begin{array}{l}5 \cdot 5 \\
6 \cdot 0 \\
6 \cdot 3 \\
7 \cdot 1 \\
7 \cdot 6\end{array}$ & $\begin{array}{l}4 \cdot 4 \\
4 \cdot 2 \\
4 \cdot 4 \\
6 \cdot 6 \\
4 \cdot 2\end{array}$ & $\begin{array}{c}\mathrm{g} \\
\mathrm{pb} \\
\mathrm{bl} \\
\mathrm{y} \\
\mathrm{g}\end{array}$ \\
\hline 42 & $\begin{array}{l}5 \cdot 5 \\
6 \cdot 0 \\
6 \cdot 3 \\
7 \cdot 1 \\
7 \cdot 6\end{array}$ & $\begin{array}{l}4 \cdot 4 \\
4 \cdot 3 \\
4 \cdot 4 \\
4 \cdot 3 \\
4 \cdot 4\end{array}$ & $\begin{array}{l}\text { yg } \\
\mathrm{pb} \\
\mathrm{yg} \\
\mathrm{bl} \\
\mathrm{y}\end{array}$ \\
\hline
\end{tabular}

* Unbuffered medium as control. 
cells fill up with polysaccharide the iodine colour of the sediment changes from yellow to green, blue and almost black. The $\mathrm{pH}$ value of the unbuffered medium fell rapidly to $4 \cdot 2$ and little iodophilic polysaccharide was produced. In the media initially buffered at $\mathrm{pH} 6 \cdot 3$ and $7 \cdot 1$ the polysaccharide content increased when the $\mathrm{pH}$ was about 5-6. After the $\mathrm{pH}$ value had fallen to $4 \cdot 4$ the organisms rapidly died, and after about $24 \mathrm{hr}$. at $\mathrm{pH} \mathbf{4 \cdot 4}$ the cultures were sterile. In some cases the iodine colour seemed to fade when the cells were kept at an acid $\mathrm{pH}$ value, probably due to autolysis of the cells and digestion of the polysaccharide by cell enzymes. In a liquid culture initially buffered at $\mathrm{pH} 6$ and incubated strictly anaerobically, the formation of polysaccharide was similar to the corresponding aerobic cultures, but the growth was not quite as dense and the $\mathrm{pH}$ value of the medium did not fall below $4 \cdot 8$.

Formation of polysaccharide by cells suspended in buffered maltose solutions Organism $18 \mathrm{C} 6$ was grown aerobically in $2 \%$ maltose broth buffered at pH 6 , for $17 \mathrm{hr}$., divided into portions $(20 \mathrm{ml}$.), centrifuged, and each sediment of

Table 4. Formation of iodophilic polysaccharide by a rumen streptococcus suspended in buffered maltose solutions after growing $17 \mathrm{hr}$. in a $2 \%$ maltose broth

Symbols for iodine stains as in Table 3. Initial iodine stain green, i.e. the cells contained a little iodophilic polysaccharide.

$\begin{array}{cc}\begin{array}{c}\mathrm{pH} \text { value of } \\ \text { maltose solution }\end{array} & \begin{array}{c}\text { Iodine stain of } \\ \text { cell sediment* }\end{array} \\ \mathbf{6} \cdot \mathbf{6} & \mathrm{yg} \\ \mathbf{6} \cdot 1 & \mathrm{pb} \\ \mathbf{5 \cdot 6} & \mathrm{pb} \\ \mathbf{5 \cdot 1} & \mathrm{pb} \\ \mathbf{4 \cdot 5} & \mathrm{g} \\ \mathbf{3} \cdot \mathbf{7} \dagger & \mathrm{yg} \ddagger\end{array}$

\footnotetext{
* After incubation for $22 \mathrm{hr}$. in buffered maltose solution.

$\dagger \mathrm{pH}$ brought down by addition of $\mathbf{H C l}$.

† Cells coagulated on bottom of bottle.
}

organisms resuspended in $2 \%$ maltose solution buffered with $0 \cdot 1 \mathrm{M}$-phosphate $(20 \mathrm{ml}$.) to the $\mathrm{pH}$ values given in Table 4 . The suspensions were incubated for a further $22 \mathrm{hr}$. and then centrifuged, and the supernatant liquids and cell sediments examined. In each broth culture the $\mathrm{pH}$ value of the medium fell to $4 \cdot 2-4 \cdot 4$ during incubation, the iodine colour of the cell sediment was green, and sugar was still present in the medium. The results of the further incubations are shown in Table 4. The $\mathrm{pH}$ values of the buffered maltose solutions did not change during the incubation. At $\mathrm{pH}$ values of $6 \cdot 1,5 \cdot 6$ and $5 \cdot 1$ the intensity of the iodine stain of the cells increased markedly on incubation, with 17,28 and $17 \%$ respectively of the total cells becoming iodophilic. In similar experiments, where the organisms were transferred to $2 \%$ glucose-1phosphate at $\mathrm{pH} 5 \cdot 5$ and buffer $(\mathrm{pH} 5 \cdot 6)$ alone, no iodophilic polysaccharide was formed. 
Since older organisms formed polysaccharide under the correct conditions it appeared of interest to see whether young rapidly growing cells formed polysaccharide when exposed to a lowered $\mathrm{pH}$ value in buffered maltose solutions. The experiment was repeated, and the initial maltose broth was incubated for only $5 \mathrm{hr}$. At this time, although the growth of organisms was good, the $\mathrm{pH}$ value of the medium had fallen only to $\mathbf{5 \cdot 8}$ and there was no detectable iodine stain in the cells. The results of incubating organisms in buffered maltose for a further $16 \mathrm{hr}$. are shown in Table 5. (Similar results were obtained after incubation for $22 \mathrm{hr}$.). The $\mathrm{pH}$ values of the maltose solutions did not alter during the incubation. Again incubation at $\mathrm{pH}$ values of 5-6 favoured the formation of iodophilic polysaccharide.

Table 5. Formation of iodophilic polysaccharide by rumen streptococci suspended in buffered maltose solutions after growing $5 \mathrm{hr}$. in a $2 \%$ maltose broth

Symbols for iodine stains as in Table 3. Initial iodine stain yellow (y), i.e. the cells contained no iodophilic polysaccharide.

$\begin{array}{cc}\begin{array}{c}\mathrm{pH} \text { value of } \\ \text { maltose solution }\end{array} & \begin{array}{c}\text { Iodine stain of } \\ \text { cell sediment* }\end{array} \\ \mathbf{6 \cdot 8} & \mathrm{y} \\ \mathbf{6} \cdot 1 & \mathrm{y} \\ \mathbf{5 \cdot 6} & \mathrm{pb} \\ \mathbf{5 \cdot 2} & \mathrm{pb}\end{array}$

* After incubation for $16 \mathrm{hr}$. in buffered maltose solution.

Table 6. Total and viable counts of rumen streptococci forming polysaccharide in buffered maltose solutions

The organisms were grown for $17 \mathrm{hr}$. in a $2 \%$ maltose broth, centrifuged off, resuspended in buffered maltose solutions $(2 \%, w / v)$ and incubated further. Counts were made by the methods described in the text.

Time of incubation (hr.)

\begin{tabular}{|c|c|c|c|c|c|c|c|c|c|c|c|}
\hline \multirow{2}{*}{$\begin{array}{c}\text { Buffered } \\
\text { maltose } \\
\text { solution } \\
\text { (pH } \\
\text { value) }\end{array}$} & $\widetilde{0}$ & 4 & 6 & 10 & 24 & \multirow[t]{2}{*}{48} & 0 & 6 & 24 & \multirow{2}{*}{\multicolumn{2}{|c|}{$\begin{array}{c}0 \\
\text { Total cells } / \mathrm{ml} \\
\left(\times 10^{-6}\right)\end{array}$}} \\
\hline & \multicolumn{5}{|c|}{ Iodophilic cells ( $\%$ ) } & & \multicolumn{3}{|c|}{ Viable cells/ml. } & & \\
\hline $5 \cdot 2$ & $<1$ & - & - & - & 21 & - & - & - & - & - & - \\
\hline $5 \cdot 7 *$ & $<1$ & 13 & 17 & 19 & 16 & - & 500 & 0 & 0 & 960 & 1120 \\
\hline $5 \cdot 7$ & $<1$ & 13 & 18 & 18 & 15 & - & 4900 & o & 0 & 960 & 1040 \\
\hline $5 \cdot 7$ & $<1$ & - & - & - & 12 & 10 & - & - & 0 & - & - \\
\hline
\end{tabular}

In a repeat of the experiment where portions of a $17 \mathrm{hr}$. culture were resuspended in buffered maltose solutions, viable and total counts and counts of the number of iodophilic organisms were made. The organisms in one portion of the culture were washed twice in sterile saline before resuspension and one suspension was incubated for $48 \mathrm{hr}$. The results (Table 6) are similar to others obtained, but the percentage of iodophilic cells was rather lower than was often found. Viable counts were made by the pour-plate method in $\mathbf{0 . 5} \%$ maltose 
agar. Total counts were made on culture dilutions stained with methylene blue on a haemocytometer slide. Iodophilic bacteria were counted on $\mathbf{5 0 0}$ cells in different parts of iodine-stained wet films. The results showed that the cells in a medium favourable for polysaccharide formation were nearly all non-viable in a medium which usually supported their growth.

\section{Formation of polysaccharide in cultures after daily adjustment of $\mathrm{pH}$ value}

This experiment was repeated a number of times, and although the percentage of iodophilic organisms varied from about 20 to $35 \%$ at $42 \mathrm{hr}$. the general trend was always the same. A typical experiment is described below. Organism $18 \mathrm{C} 6$ was inoculated into $100 \mathrm{ml}$. of a medium containing $2 \%$ maltose, buffered at $\mathrm{pH} 6$, and the culture incubated aerobically. At $18 \mathrm{hr}$. the $\mathrm{pH}$ value of the medium had fallen to $4 \cdot 0$ and the iodine colour of the sediment was green, with $1 \%$ of iodophilic cells. The $\mathrm{pH}$ value was adjusted to $5 \cdot 7$ with $\mathrm{NaOH}$ and incubation continued. At $24 \mathrm{hr}$. the $\mathrm{pH}$ was $5 \cdot 4$ and the iodine colour of the cell sediment purple. At $42 \mathrm{hr}$. the $\mathrm{pH}$ had fallen to $4 \cdot 2$ and the iodine colour of the cell sediment was a dark purple with $33 \%$ iodophilic cells (Pl. 1, fig. 2). The $\mathrm{pH}$ value was again adjusted to $5 \cdot 7$ and incubation continued, at $48 \mathrm{hr}$. the $\mathrm{pH}$ being 5.6. At $66 \mathrm{hr}$. the $\mathrm{pH}$ was $4 \cdot 4$ and the number of iodophilic cells $49 \%$ of the total. The $\mathrm{pH}$ value was readjusted, but by this time there was only a trace of sugar in the medium, and at $90 \mathrm{hr}$. the $\mathrm{pH}$ value had fallen only to $4 \cdot 8$. The number of iodophilic cells had also decreased to $38 \%$ and many cells were disintegrating.

It was noted that when the cultures had become suitable for polysaccharide formation the cells had become Gram-variable and many were irregular in appearance like cells suspended in buffered maltose. Thus it seemed of interest to determine the number of viable bacteria in these cultures forming polysaccharide. A $2 \%$ maltose broth buffered at $\mathrm{pH} 6(100 \mathrm{ml}$.) was inoculated as above and incubated for $17 \mathrm{hr}$.; the $\mathrm{pH}$ value of the medium had then fallen to 4.2 and the iodine stain of the cell sediment was green. The $\mathrm{pH}$ was raised to 5.7 and the culture reincubated. At the times stated in Table 7 viable and total counts were made. After incubation for $24 \mathrm{hr}$. the $\mathrm{pH}$ had fallen to 4.5 , and the iodine stain of the cell sediment was a deep purple with $33 \%$ of the cells iodophilic. In another similar experiment the total number of viable organisms initially present was much higher, but there was a more marked fall in numbers on adjusting the $\mathrm{pH}$ value. This was followed by a rapid increase in numbers at about 5-6 hr. as in Table 7, and the total and viable counts after $24 \mathrm{hr}$. were almost the same as those given in the table.

In similar experiments, where the $\mathrm{pH}$ value of a $2 \%$ glucose broth was raised to $\mathbf{5 . 7}$ every $24 \mathrm{hr}$., no iodophilic polysaccharide was produced. An attempt was also made to prepare a $2 \%$ amylose broth by dissolving amylose in water by autoclaving and adding the remainder of the constituents as a concentrated solution, but the amylose began to retrograde almost immediately, and although a heavy inoculum was made into the medium no growth occurred. The experiments were therefore abandoned. 


\section{Partial purification of the iodophilic polysaccharide}

In initial experiments the isolation of the polysaccharide was attempted by autoclaving the whole cells in neutral solution, and by extracting with sodium hydroxide at different concentrations and temperatures. Very little of the polysaccharide was extracted by these methods so it was decided to try to rupture the cells and then extract the polysaccharide with chloral hydrate. Shaking in suspension in a tissue disintegrator (Mickle, 1948) with ballotini no. 12 glass beads (Chance Ltd., Smethwick), or grinding a dry powder of

Table 7. Viable and total counts during the formation of iodophilic polysaccharide in rumen streptococci in a liquid medium after adjustment of the $\mathrm{pH}$ to $\mathbf{5 \cdot r}$

The organisms were grown for $17 \mathrm{hr}$. in a $2 \%$ maltose broth, the pH of the broth was then raised to $5 \cdot 7$ and incubation continued. Counts were made by the methods described in the text.

$\begin{array}{ccc}\begin{array}{c}\text { Time } \\ \text { (hr.) }\end{array} & \begin{array}{c}\text { Viable cells } \\ / \text { ml. } \times 10^{-3}\end{array} & \begin{array}{c}\text { Total cells } \\ / \text { ml. } \times 10^{-6}\end{array} \\ 0^{*} & 25 & 800 \\ 1 \dagger & 16 & 720 \\ 2 & 20 & 960 \\ 3 & 35 & 960 \\ 4 & 55 & 880 \\ 5 & 75 & 800 \\ 6 & 270 & 880 \\ 7 & 1500 & 960 \\ 24 & 5510 & 1520\end{array}$

* Before raising $\mathrm{pH}$. $\dagger$ Immediately after raising $\mathrm{pH}$ to $5 \cdot 7$.

bacteria in vacuo with glass beads (Gunsalus \& Umbreit, 1945) followed by extraction, gave very small yields of polysaccharide. A method giving more disintegration of the cells and a better yield of polysaccharide was afforded by grinding the wet cells with alumina (McIlwain, 1948), followed by extraction. However, it was found that the alumina dissolved in the chloral hydrate used for extraction, and was later reprecipitated, giving polysaccharides with a high ash content. The alumina was therefore replaced by carborundum powder. A partial purification of the polysaccharide has been achieved by this method which is described briefly below.

The streptococcus $18 \mathrm{C} 6$ was grown aerobically for 4 days on agar plates of basal medium $+2 \%$ maltose. The colonies were then washed off the plates with a jet of water, filtered through glass wool and centrifuged. The organisms were resuspended in water, again filtered, and centrifuged. After washing twice more with water the organisms were frozen to $-20^{\circ}$ overnight and the solid mass mixed with twice its weight of cold carborundum (Grade $4 \mathrm{~F}$; Griffin and Tatlock Ltd., London) in a mortar cooled to $0^{\circ}$, and then ground by hand for $15 \mathrm{~min}$. A little more carborundum was added when necessary to keep the paste almost solid, and the mortar cooled at intervals. The whole mass was next extracted twice with $33 \%$ (w/v) chloral hydrate at $80^{\circ}$ (Meyer \& Bernfeld, 1940). The chloral hydrate extract, after centrifuging, was filtered 
through a sintered glass filter (grade 5), then poured slowly into well-stirred excess acetone (3-4 vol.), and the whole allowed to stand overnight at $2^{\circ}$. The precipitated polysaccharide was removed by centrifuging, washed and dried by trituration with acetone and ether. Such preparations contained about $0 \cdot 8 \%$ nitrogen and $13 \%$ ash. To decrease the protein and ash contents the following procedure was carried out.

Several combined preparations were wetted with ethanol and dissolved in $0 \cdot 1 \mathrm{~N}-\mathrm{NaOH}$ by heating in a boiling water-bath for a few minutes. After neutralizing, to each $25 \mathrm{ml}$. was added hydrated sodium acetate (1 g.), butanol $(0.5 \mathrm{ml}$.), and chloroform (5 ml.). The whole was shaken for $10 \mathrm{~min}$. and centrifuged. The aqueous layer was dialysed for 2 days against running distilled water; then the non-diffusing polysaccharide was precipitated with ethanol ( 2 vol.), spun down, and dried by trituration with ethanol and ether.

The yield in the first stage of the preparation was very small, only some $5 \%$ of the dry weight of bacteria. A typical analysis of the polysaccharide was: 'starch' content, $\mathbf{5 9 \cdot 2} \%$, from reducing sugar estimated as glucose by a copper reagent (Somogyi, 1952) in conjunction with Nelson's reagent (1944), after acid hydrolysis under the conditions described for potato starch by Pirt \& Whelan (1951); blue value, 17·1 'Eel' colorimeter units (Hobson \& MacPherson, 1952); total nitrogen (micro-Kjeldahl), $0.2 \%$; ash after total combustion, $11.1 \%$. The main sugar in the hydrolysate was glucose, but some preparations contained a trace of galactose and possibly rhamnose. By the formamide chromatogram technique of Nussenbaum (1951) the polysaccharide was shown to contain some short-chain iodine-staining dextrins which migrated with the solvent front. The conversion to reducing sugars, estimated as maltose, by soya-bean $\beta$-amylase was $68 \%$ of the estimated 'starch' content, suggesting the presence of some amylopectin type polysaccharide. A small amount of maltotriose was detected in the products of $\beta$-amylolysis which might have come from dextrins of an uneven number of glucose units. The properties of the different impure preparations of the polysaccharide so far made seem to be similar, but all the polysaccharide is not extracted from the cell sediment. The nature of the unhydrolyzable material in the polysaccharide preparations is at present unknown, but it is hoped that this can be removed when the polysaccharide is prepared on a larger scale from liquid cultures.

\section{DISCUSSION}

The formation of intracellular iodine-staining polysaccharide in some calf rumen streptococci has been demonstrated. However, all the organisms were capsulated before visible formation of iodophilic polysaccharide took place (and also in glucose broths) and the capsules appeared to persist even when many iodophilic bacteria were present. This capsule is most probably mainly polysaccharide in nature (Hobson \& MacPherson, 1954). It is also possible that other polysaccharides are present in the cells, but in the following discussion 'polysaccharide' signifies intracellular iodine-staining material.

In an investigation of the amylase of a sheep rumen streptococcus, which 
appears to be identical with the calf rumen organisms used here, it was shown that the principal products of the hydrolysis of the amylose component of starch were maltose and maltotriose (Hobson \& MacPherson, 1952); the same products, and some branched-chain oligosaccharides, are formed from amylopectin. As expected, since the rumen streptococci build up iodine-staining polysaccharide when digesting starches in vivo and in vitro, the maltose and maltotriose formed during the hydrolysis of starch can be utilized for the synthesis of polysaccharide. Glucose, which is formed in only small amount by the rumen streptococcus amylase, is not so utilized. The maltotriose preparation contained traces of maltose and glucose, but the amount of maltose present would not alone be sufficient to form polysaccharide. There are two possible methods of enzymic formation of 'starch' from maltose, one by an amylomaltase type of enzyme (Monod \& Torriani, 1948) which produces polyglucose and glucose from maltose; the other by a maltose phosphorylase producing $\alpha$-glucose-1-phosphate from maltose, and a phosphorylase converting the glucose-1-phosphate to amylose. Fitting \& Doudoroff (1952) made enzyme preparations from Neisseria meningitidis which produced $\beta$-glucose-1phosphate from maltose. Both enzyme systems would then need a type of Q-enzyme to form the amylopectin component of a normal starch. The second possibility appears to be ruled out by the lack of utilization of glucose-1phosphate by cells grown on glucose or maltose. Amylomaltase forms mainly reducing oligosaccharides 4-6 glucose units in length, unless the glucose formed at the same time is removed by the glucose oxidase notatin, when a blue iodine-staining polysaccharide is formed (Monod \& Torriani, 1948; Doudoroff, Hassid, Putman, Potter \& Lederberg, 1949). If an amylomaltase type of enzyme operates in the streptococci then the glucose formed must be utilized by the cells, as only maltotriose and a little material of smaller $\boldsymbol{R}_{\boldsymbol{r}}$ value was detected in chromatograms of an extract of the agar or of the water used to wash the colonies from the agar, during the preparation of the polysaccharide. Doudoroff et al. (1949) found no glucose in the medium when Escherichia coli, containing an amylomaltase, utilized maltose. It seems likely that maltotriose is an intermediate in the formation of bacterial polysaccharide from maltose, and this suggests that only glucose units are added to the growing molecules during the formation of polysaccharide, and not maltose units as such.

It might be expected that all dextrins and starch fractions would be equally effective in the formation of polysaccharide by these organisms, but apparently the linear molecules are not easily utilized, even though they support the growth of the bacteria. The simplest explanation of this is the poor solubility of the amylose type molecules. In a liquid medium amylose rapidly retrogrades and in the agar media, although there was sufficient amylose in solution to give a dense iodine colour before hydrolysis by the growing bacteria, some of it was out of solution, and it is quite possible that after the hydrolysis products had been utilized for growth of the bacteria there was not sufficient sugar left for the formation of polysaccharide (a certain minimum concentration of maltose is needed; Table 2). Increasing the concentration of amylose in the plates 
might not proportionately increase the amount of amylose actually in true solution and available for the bacteria. Increasing the concentration of amylose dextrins, the smaller molecules of which do not retrograde as easily as the large ones, might greatly increase the amount of polysaccharide in solution. Amylose glycollate is easily soluble and does not retrograde, whilst amylopectin, glycogen and native starches are all more stable in solution than separated and alcohol dried amylose. It does not appear that an unfavourable $\mathrm{pH}$ value alone was responsible for the non-production of polysaccharide because flooding some of the colonies on a $2 \%$ amylose plate, after $2 \frac{1}{2}$ days of

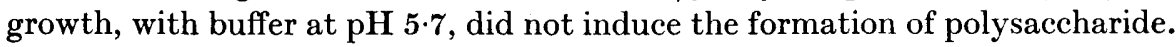

From the tests of liquid media it would seem that the $\mathrm{pH}$ value of the colonies on agar plates must become stabilized at 5-6 to allow the formation of polysaccharide. An attempt was made to test this point, but all that could be said was that the general $\mathrm{pH}$ of the plates was about 6 ; the $\mathrm{pH}$ value of the colonies was not ascertainable.

When the plate cultures were flooded with iodine it was noted that in many cases only the centre of the colonies stained blue, the outer zones of, presumably, younger cells were almost colourless. The results of viable counts showed that after some hours at a low $\mathrm{pH}$ value the cells lost their ability to reproduce in a medium in which they usually grew rapidly. In young cultures in liquid and solid media no iodine-staining cells were seen. These and other results suggest that the ability to store polysaccharide is possessed only by non-viable or resting organisms, and is not connected with a rapid growth of the bacteria. These conclusions are supported by the work of Smith \& Baker (1944), who found that the number of iodophilic organisms which accumulated during the incubation of rumen contents with maltose in vitro was more than might be assumed to result from multiplication alone. It appeared, therefore, that the storage of polysaccharide was taking place not, or not only, in dividing organisms but in many of those already present. It is possible that polysaccharide is being produced in all organisms in maltose or starch media, but that it is rapidly utilized by growing organisms, and an acid medium, or one containing no nitrogen source for growth, causes the inactivation first of enzymes of utilization and polysaccharide accumulates until the enzymes forming it become inactive.

The general $\mathrm{pH}$ value of the sheep's rumen is about 6-7. 'This appears to be unfavourable for the formation of bacterial polysaccharide by the streptococci. However, the bacteria attacking starch and cellulose are found in close contact with these materials, very often in cavities (see photomicrographs in Klein et al. 1937; Baker \& Nasr, 1947; Baker et al. 1950). The rapid formation of acids by the organisms might cause the immediate surroundings of the bacteria to be at a lower $\mathrm{pH}$ value than the general body of the rumen and thus the conditions for polysaccharide formation might be present.

The formation of iodophilic polysaccharide from maltose appears to be a property of other amylolytic group $\mathrm{D}$ streptococci. The sheep rumen streptococci formed polysaccharide under the correct conditions as did Streptococcus bovis no. 8177 and 8133 (National Collection of Type Cultures). S. faecalis 
(NCTC 775) and S. faecalis isolated from the rumen of the sheep in our own laboratories were non-iodophilic under the same conditions, but they were non-amylolytic.

The iodine-staining polysaccharides formed by bacteria vary in composition. Aubert (1951) isolated a glycogen-like polysaccharide from Bacillus megaterium. The starch of Corynebacterium diphtheriae, like normal plant starch, is composed of amylose and amylopectin (Carlson \& Hehre, 1949), and the starch of a rumen strain of Clostridium butyricum seemed to be amylopectin-like in character (Hobson \& Nasr, 1951). The composition of the iodophilic polysaccharide of these rumen streptococci is not completely elucidated, but the results above show that it is 'starch-like' in that it is a polyglucose with presumably $\alpha-1: 4$ linkages as it gives an iodine stain and is susceptible to hydrolysis by $\beta$-amylase. The incomplete hydrolysis by $\beta$-amylase suggests that some branch linkages are present, but the extent of the hydrolysis and also the iodine colour and blue value $(c .17)$ precludes the presence of only amylopectin. The blue value of amylopectin on the Eel colorimeter scale is about 5 , that of potato starch about 16 , and amylose about 50 . Whilst the blue value of the polysaccharide is about that of potato starch the colour of the iodine stained solution at this concentration is purplish, unlike that of starch, and this and the results of the formamide chromatograms suggest the presence of molecules of short chain length. It is possible that these represent stages in the formation of the polysaccharide and that their amount may vary in different cells. From the results obtained to date it would appear that this bacterial polysaccharide does not fit into any of the usual classifications of starch, amylose and amylopectin or glycogen, and its properties will be the subject of further investigations.

We wish to express our thanks to Dr A. E. Oxford for helpful discussion, and Miss M. G. Garvock and Mr T. Begg for technical assistance.

\section{REFERENCES}

Aubert, J. P. (1951). Étude biochimique du rendement matériel de croissance d'une bacterie aérobie. Bacillus megatherium. Ann. Inst. Pasteur, 80, 644.

BAKER, F. \& NASR, H. (1947). Microscopy in the investigation of starch and cellulose breakdown in the digestive tract. J. R. Micr. Soc. 67, 27.

Baker, F., Nasr, H., Morrice, F. \& Bruce, J. (1950). Bacterial breakdown of structural starches and starch products in the digestive tract of ruminant and non-ruminant animals. J. Path. Bact. 62, 617.

Bourne, E. J., Donnison, G. H., Haworth, N. \& Peat, S. (1948). Thymol and cyclohexanol as fractionating agents for starch. J. chem. Soc. p. 1687.

Bourne, E. J., Haworth, N., Macey, A. \& Peat, S. (1948). The amylolytic degradation of starch. A revision of the hypothesis of sensitization. J. chem. Soc. p. 924.

Carlson, A. S. \& Hehre, E. J. (1949). Composition of the starch synthesized from glucose-1 phosphate by diphtheria bacilli. J. biol. Chem. 177, 281.

Dovdoroff, M., Hassid, W. Z., Putman, E. W., Potter, A. L. \& Lederberg, J. (1949). Direct utilization of maltose by Escherichia coli. J. biol. Chem. 179, 921.

Fitring, C. \& Doudonoff, M. (1952). Phosphorolysis of maltose by enzyme preparations from Neisseria meningitidis. J. biol. Chem. 199, 153. 
Gunsalus, I. C. \& Umbreit, W. W. (1945). The oxidation of glycerol by Streptococcus faecalis. J. Bact. 49, 347.

Higginbottom, C. \& Wheater, D. W. F. (1954). The incidence of Streptococcus bovis in cattle. J. agric. Sci. 44, 434.

Hobson, P. N. \& MacPherson, M. J. (1952). Amylases of Clostridium butyricum and a Streptococcus isolated from the rumen of the sheep. Biochem. J. 52,671.

Hobson, P. N. \& MacPherson, M. J. (1954). Some serological and chemical studies on materials extracted from an amylolytic streptococcus from the rumen of the sheep. Biochem. J. 57, 145.

Hobson, P. N. \& NaSR, H. (1951). An amylopectin type polysaccharide synthesized from sucrose by $C l$. butyricum. J. chem. Soc. p. 1855 .

Hobson, P. N., Pirt, S. J., Whelan, W. J. \& Peat, S. (1951). The enzymic synthesis and degradation of starch. Part XIII. Improved methods for the fractionation of potato starch. J. chem. Soc. p. 801.

Klein, W., Schmid, H. \& Studt, E. (1937). Die biologischen Vorgänge bei der Verwertung der Amide speziell der Molasseamide und des Stromeiweisses durch den Wiederkäuer. Z. Zücht. B39, 135.

MacCready, R. M. \& HAssid, W. Z. (1944). The preparation and purification of glucose-1 phosphate by the aid of ion-exchange adsorbents. J. Amer. chem. Soc. 66, 560 .

McIlwain, H. (1948). Preparation of cell free bacterial extracts with powdered alumina. J. gen. Microbiol. 2, 288.

MacPherson, M. J. (1953). Isolation and identification of amylolytic streptococci from the rumen of the sheep. J. Path. Bact. 66, 95.

ManN, S. O. \& Oxford, A. E. (1955). Relationships between viable saccharolytic bacteria in rumen and abomasum of the young calf and kid. J. gen. Microbiol. $12,140$.

Masson, M. J. (1954). Microscopic studies of the gut flora of the hen with special reference to the breakdown of starches. 10th World's Poultr. Congr., Edinburgh. Section Papers, p. 105.

Meyer, K. H. \& Bernfeld, P. (1940). Recherches sur l'amidon, v. l'amylopectine. Helv. chim. acta, 23, 875.

MickLE, H. (1948). Tissue disintegrator. J. R. Micr. Soc. 68, 10.

Moir, R. J. \& Masson, M. J. (1952). An illustrated scheme for the microscopic identification of the rumen micro-organisms of the sheep. J. Path. Bact. 64, 343.

Monod, J. \& Torriani, A. (1948). Synthèse d'un polysaccharide du type amidon aux dépens du maltose, en présence d'un extrait enzymatique d'origine bactériènne. C.R. Acad. Sci., Paris, 227, 240.

NASR, H. \& BAKER, F. (1949). Microbial synthesis of iodophile polysaccharide by a Clostridium from the caecum of the pig. Nature, Lond. 164, 745.

Nelson, N. (1944). A photometric adaptation of the Somogyi method for the determination of glucose. J. biol. Chem. 153, 375.

Nussenbaum, S. (1951). Differentiation of amylopectin, amylodextrins, and amylose fatty acid complexes. A spot test. Analyt. Chem. 23, 1478.

OXFord, A. E. (1951). Conversion of certain soluble sugars to a glucosan by holotrich ciliates in the rumen of the sheep. J. gen. Microbiol. 5, 83.

Peat, S., Bourne, E. J. \& Thrower, R. D. (1947). A new indicator for iodometric analysis. Nature, Lond. 159, 810.

Pirt, S. J. \& Whelan, W. J. (1951). The determination of starch by acid hydrolysis. J. Sci. Fd Agric. p. 224.

QuiN, J. I. (1943). Studies on the alimentary tract of merino sheep in South Africa. VII. Fermentation in the forestomachs of sheep. Onderstepoort. J.vet.Sci.18,91.

Smith, J. A. B. \& BAKER, F. (1944). The utilization of urea in the bovine rumen. 4. The isolation of the synthesized material and the correlation between protein synthesis and microbial activities. Biochem. J. 38, 496. 
Journal of General Microbiology, Vol. 13, No. 3

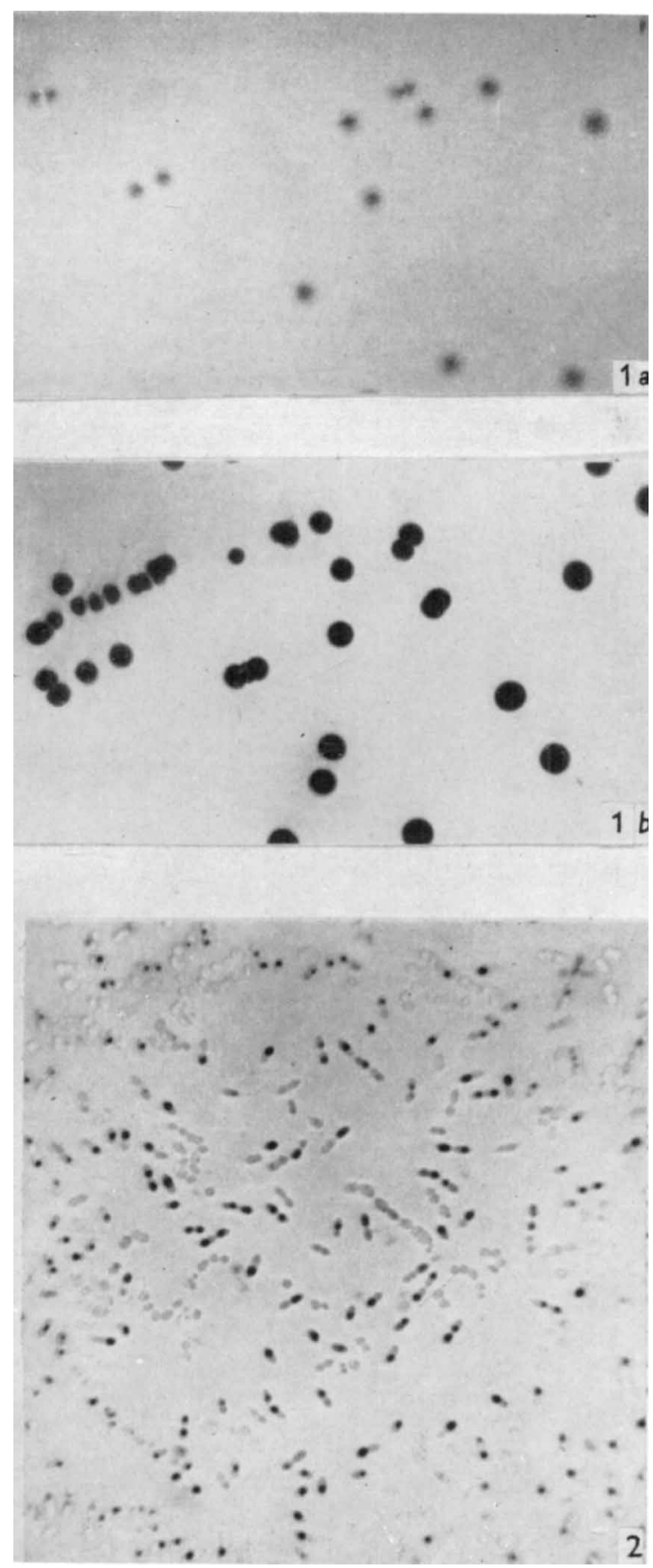

P. N. Hobson \& S. O. Mann--Iodophilic streptococci. Plate 1 
Somogyi, M. (1952). Notes on sugar determination. J. biol. Chem. 195, 19.

VAN DER WATH, J. G. (1948). Studies in the alimentary tract of merino sheep in South Africa. XI. Digestion and synthesis of starch by rumen bacteria. Onderstepoort J. vet. Sci. 23, 367.

Whistler, R. L. \& Durso, D. F. (1950). Chromatographic separation of sugars on charcoal. J. Amer, chem. Soc. 72, 677.

\section{EXPLANATION OF PLATE}

Fig. 1. Iodine-stained colonies of rumen streptococei after 3 days on $(a)$ glucose, $(b)$ maltose agar. Colonies on maltose with iodine staining cells are blue-black, those on glucose are yellow-brown. $\times 2$.

Fig. 2. Wet preparation, iodine stained, of rumen streptococci from maltose broth $24 \mathrm{hr}$. after adjustment of $\mathrm{pH}$ from $4 \cdot 0$ to 5.7. Iodophilic polysaccharide appears black. $\times 1000$.

(Received 12 April 1955) 